\title{
Should we blame Calvinism for the development of apartheid in South Africa? A perspective from the Reformed Churches in South Africa: A case study
}

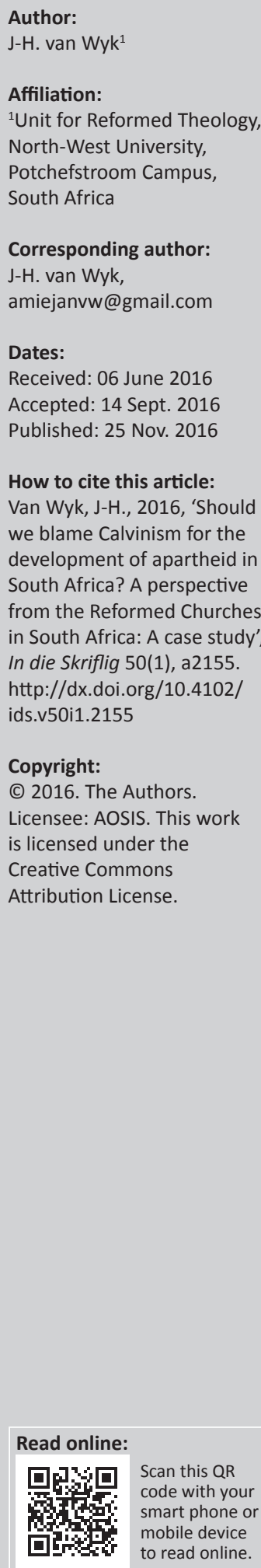

\begin{abstract}
In his book The Irony of Apartheid (1981), I. Hexham argues that Calvinists - also those from Potchefstroom - formulated and promoted the ideology of apartheid. In this article this statement is investigated by comparing it to the view of the Dutch historian, Gerrit Schutte, who blamed Hertzog, Malan and the volksnasionaliste [nationalists] for the development of the Afrikaner ideology. The views of Calvinist individuals and organisations, especially some hailing from Potchefstroom as well as those of the Gereformeerde Kerke van Suid-Afrika (GKSA) are examined and a far more nuanced conclusion is reached. The article ends with some short remarks on the everlasting question about the relation between (national) unity and (cultural) diversity.
\end{abstract}

\section{Introduction}

Some people hold a view that 'Calvinists', ${ }^{1}$ also from Potchefstroom, formulated, supported, propagated and promoted the political ideology of apartheid as Hexham (1981:24, 187-188) argues in his book The Irony of Apartheid (see also Moody 1975:170-179). Is it correct to blame J.D. $\mathrm{du}$ Toit (Totius), the well-known Bible translator, psalmist and theologian, and the GKSA for being the fathers of apartheid as was done by Botha (1986:139-141, 152-154), De Gruchy \& De Gruchy (2004:31-32) and Kinghorn (1986:101; also see Giliomee 2003:362; Louw 2001:161, 228-231; Smit 2007:106)?

It cannot be denied that prominent Calvinist theologians and philosophers of the Afrikaans churches supported the ideology of apartheid in writings and speeches. The following names could be mentioned here: A.B. du Preez, E.P. Groenewald, F.J.M. Potgieter, A.P Treurnicht and J.D. Vorster from the Nederduitse Gereformeerde Kerk (NGK); P.S Dreyer, A.D. Pont and H.P. Wolmarans from the Hervormde Kerk (NHKA); J.D. du Toit (see Van Wyk 1993:41-43) and H.G. Stoker (see Van Wyk 1993:49-50; 2001:188-213) from the Gereformeerde Kerke (GKSA). It is without a doubt that Totius, in his address at the volkskongres in 1944 in Bloemfontein, gave a theological exposition and justification of apartheid - which, 71 years later, led to the removal of his statue from the campus of North-West University in 2015. But was he the first to develop a theology of apartheid? Was the Potchefstroom University for Christian Higher Education (PU for CHE) - now the North-West University (NWU) - and the GKSA the breeding-place for apartheid?

Thorough investigation shows that Totius was not the first theologian to formulate a theology of apartheid. Totius refers with acclamation to the studies by the NGK missionary J.G. Strydom, namely Die rassevraagstuk in Suid-Afrika (Strydom 1941) and Die rassevraagstuk en die toekoms van die blankes in Suid-Afrika (Strydom 1942) in which Strydom affirmed and supported apartheid. Even before Strydom, the NGK minister F.G. Badenhorst completed a doctoral thesis (at the Free University in Amsterdam!) in 1939 (Badenhorst 1939) on the subject Die rassevraagstuk, veral betreffende Suid-Afrika, in die lig van Gereformeerde etiek (see Schutte 2005:655) in which he argued in favour of separation. ${ }^{2}$

But let us start the story from the very beginning.

\section{Phase 1: Protagonists for patriotism (1859-1944)}

Phase 1 can be divided into two sections. In section one the emphasis is on the events related to the second Anglo-Boer War (ABW2) - now called the South African War (1899-1902). Section two focuses on the events that relate to the Second World War (WW2) (1939-1945). ${ }^{3}$

1.i use this controversial term Calvinists for the sake of argument. It refers to Reformed Christianity - which will later on be clarified.

2.See Giliomee 2003:459: 'DRC ministers and missionary strategists were first in the field to formulate an apartheid ideology.'

3.See Van Wyk 1993:41-60 and 2015:276-280. 
The GKSA came into existence in 1859 in Rustenburg in the Zuid-Afrikaansche Republiek (ZAR), later called Transvaal. The founder of the church, Dirk Postma, soon moved to Burgersdorp in the Cape Colony that was under British rule. In 1869 the GKSA started a (flourishing) theological school at Burgersdorp with Postma and J. Lion Cachet as lecturers the latter a passionate patriot and language activist. Patriotism flourished (Van der Vyver 1969:83, 85). During this early period the events, which accompanied the ABW2, had a devastating effect on South African society and churches as a whole (see Van der Vyver 1969:83-108). The theological school at Burgersdorp was periodically closed and some students joined the Boer commandos, three students lost their lives, others were banned and Prof Cachet detained but later released. Totius himself served as a veldprediker [minister in the field] for nine months and then left South Africa to complete his doctorate at the Free University of Amsterdam.

The ABW2 radically changed the South African scene. It stimulated Afrikaner patriotism and nationalism immensely. It was, in essence, a conflict between Afrikaner nationalism and British imperialism. During the war 34000 Afrikaner people lost their lives (of which 28000 were women and children in concentration camps) as well as 20000 black people. Many church buildings and about 30000 houses (see Pretorius 1998:56) were destroyed in the Orange Free State and the ZAR, and many congregations scattered (see Bossenbroek 2012:435; Nasson in Giliomee \& Mbenga 2007:220). ${ }^{4}$ Today it would be described as 'a crime against humanity'; even 'a crime against Christianity', and yet, up to now, there has been no explicit articulation of remorse from the side of the English-speaking churches in England or in South Africa - a fact which was experienced with regret and disappointment by Afrikaans-speaking Christians during the years of apartheid when the English-speaking churches (correctly) criticised the system of apartheid. In this regard De Gruchy (1998:7-8) refers to the 'atrocities of the concentration camps' and that it was the policy of the British government, at that time, to destroy the Afrikaner culture. He continues: 'Tragically, the role of the English-speaking churches in all this was entirely jingoistic - not only was there no criticism of the imperial war effort, there was total support of it. ${ }^{5}$

In 1905 the theological school of the GKSA was moved to Potchefstroom, inter alia, to escape the influence of the British-orientated Cape Province (Van der Vyver 1969:104). Although Transvaal lost its freedom after ABW2 the province was more Afrikaans-orientated than the Cape Province.

The PU for CHE, standing in the Christian National tradition, can be seen as a development of the theological school of the GKSA. It reflected the Calvinist theocratic vision that the

\footnotetext{
4.Pretorius (1998:81) refers to 27927 white people and 14154 black people who died in concentration camps. The book of Wessels and Raath (2012) gives a vivid exposition of the crimes that took place during the ABW2.

5.Archbishop Desmund Tutu is of the opinion that the bitterness between Afrikaans- and English-speaking South Africans could have been avoided if there had been a proces of a truth and reconciliation commission a century earlier (see Allen 2006:352).
}

Word of God enlightens and the rule of Christ encompasses every aspect of human life - also science - as well as the Kuyperian view that the church as an organism should Christianise society through Christian organisations, political parties, schools and universities (Kuyper 1959). ${ }^{6}$ It is therefore important to distinguish clearly between what the GKSA as a church decided and practised, on the one hand, and on the other hand what the Calvinist organisations, the PU for CHE, the Afrikaans Calvinistic Movement (ACM), started in 1953 and later renamed as Reformational Movement of Southern Africa (REMSA), and its magazine Word and Action did although the two were always closely related to each other. Worth mentioning is also the Institute for the Promotion of Calvinism (later renamed as Institute for Reformational Studies) led by Prof Bennie van der Walt. ${ }^{7}$ These Calvinist organisations were often inspired and directed by Calvinists who were members of the GKSA. Two principles, viz. freedom and justice played a decisive role in almost all the approaches used through the years.

In this regard, one should also refer to another prominent member of the GKSA, namely Paul Kruger who was president of the ZAR (1877-1902). He was inspired by patriotism and nationalism, and in many of his speeches would compare the experiences and vicissitudes of the Afrikanervolk with that of old Israel in the Bible, ${ }^{8}$ but then we should remember that the volk had to obey the Law of God of which the key characteristics were freedom, love and justice (Mi 6:8). The strive for political freedom dominated his speeches - mostly directed against a very aggressive British imperialism. He never subscribed to the heresy that all black people were inferior and eternally doomed (Giliomee 2003:179). (During the fierce debates on race and racism during 2015-2016 in South Africa, Moloto Mothape of the African National Congress (ANC) made the contentious statement that Kruger was a 'bloodthirsty murderer', 9 a typification that some historians would use for Shaka (see Edgecombe in Cameron \& Spies 1991:118; Visagie in Pretorius 2012:110). ${ }^{10}$

The next event that brought about much turmoil was WW2 (1939-1945), especially when the South African government, against Afrikaner sentiment, decided to join the war, which meant joining the old enemy, England. High profile Calvinists

6.The Kuyperian concept of Christian national education - the kingship of Christ should be obeyed in all spheres of life - was such a fundamental idea among should be obeyed in all spheres Calvinists that senator Jan de Klerk (a member of the GKSA) in 1967 initiated the promulgation of a law (Law no. 39) in Parliament which ruled that all education in South Africa should be Christian in character (De Klerk, Duvenage \& Van Wyk 1972:351) - a well meant but totalitarian approach, because it put non-Christian under moral constraint. The fact that today we have a religious friendly Constitution (Republic of South Africa 1996) as far as the teaching of religion in schools is concerned (Art. 31), may be ascribed to this old (Christocratic) Calvinist approach although coercive measures are excluded now.

7.This Institute, under the leadership of Van der Walt, published many important and even critical studies on the South-African socio-political situation. Other names that could be mentioned here are, inter alia, Professors Koos Vorster, Koos van Rooy, Flip Buys, Ponti Venter, Jacques van der Elst and Joh van Tonder.

8.See Du Plessis (1952:12) where D.W. Kruger (in the preface) refers to the fact that the parallel between the 'Afrikaner Trekkervolk' and Israel is striking in the speeches of Kruger.

9.See the classic study on Paul Kruger by Kruger $(1961,1963)$.

10.Edgecombe also referred to the fact that when Shaka's mother died in 1827, 7000 people were killed, because they did not mourn enough (Cameron \& Spies 1991:119). Such emotional arguments are, however, not very helpful. 
were involved in many disputable events. Prof Joon van Rooy, rector of the Potchefstroom University and chairman of the Afrikaner Broederbond, played a leading role in reconciling and uniting opposing Afrikaners and stimulating debate for a free and independent republic. During 1940 the government soldiers launched an attack on the students of the Potchefstroom University. Prof H.G. Stoker, a prominent philosopher and advocate of Christian science, was sent to an internment camp at Koffiefontein.

It was during these times of international uncertainty and turmoil that Potchefstromers initiated the threefold studies Koers in die Krisis $(1935,1940,1941)$, joined by international authors, in which they focused on the meaning and effect of Calvinism in society. However, the stress on nationalism is apparent in many of the articles (Van der Schyff 2003:393-396).

During the wartime (1944), Totius delivered his widely discussed and disputed address in favour of apartheid in Bloemfontein during a volkskongres. He took his starting point in the creation ordinances of God as well as the providence and council of God that ordained different nations and separate volke (Ac 17:26) and then spiritualised the unity in Christ. ${ }^{11}$

A name that should also be mentioned here is that of Prof H.G. Stoker, an influential philosopher from Potchefstroom, well known for his Christian approach to science and his 'philosophy of creation'. Although he rejected (German) national socialism, he yet argued in favour of separate development - although in a nuanced form. As was the case with Totius, Stoker also minimised the relevance and implications of the message of Christ (Christology) for social ethics and could not free himself fully from the apartheid ideology. ${ }^{12}$

It cannot be denied that during this first phase the Calvinists of Potchefstroom endorsed a policy of segregation to safeguard a Christian civilisation and culture - as it was formulated then (Potgieter 1998:117; Van der Schyff 2003:554).

In 1948 the political situation in South Africa changed when the Herenigde Nasionale Party (HNP) of Dr DF Malan came into power and started to implement a policy of apartheid. This policy was developed, refined and intensified until 1990 when Mr F.W. de Klerk initiated a new dispensation ${ }^{13}$. The apartheid policy was aimed at regaining political freedom for Afrikaner people, which was lost during the ABW2, but it was a policy that totally ignored the freedom and humaneness of the black majority and could never be morally justified.

11.D’Assonville (1993:270) sharply criticised me because of my critique on Totius, but he himself never evaluated the presentation of Totius in 1944. See my reaction in Van Wyk (1994:681).

12.For an evaluation of the views of Stoker, see Van Wyk (2001:188-213). Ntoane (1983) one-sidedly criticises Stoker and Heyns as decadent Calvinists. Heyns gradually developed a more critical stance towards apartheid (see Van Wyk 2001:214-237).

13.Van Jaarsveld (1979) distinguishes three phases in the development of the apartheid policy: a first phase of ideological, doctrinal and negative apartheid (Malan and Strydom); a second phase of separate development (Verwoerd) and a third phase of political change as reaction against the revolutions in Africa (Vorster).
However, it cannot be denied that the ABW2 'was one of the most important causes for the apartheid policy' (Scholtz 2008:48). ${ }^{14}$

\section{Phase 2: Critical re-evaluation - 'The voice of Potchefstroom' (1949-1990)}

A new period of critical re-evaluation started among Calvinists in Potchefstroom and the GKSA. This new period was characterised by questions such as: How should we relate land and nation, Christian and national, unity and diversity, freedom and justice? And above all: How should we interpret Scripture in this regard?

With the inauguration ceremony of the Voortrekker Monument in 1949 Dr D.F. Malan coined the slogan: 'Glo in jouself, glo in jou volk, glo in jou God' ['Believe in yourself, believe in your nation, believe in your God' - author's translation], but this slogan was queried by the Calvinist, L.J. du Plessis, of Potchefstroom: it is unacceptable to have 'faith in' human beings and to put it on the same level as 'faith in' God, he argued. It is a categorical mistake (see Du Plessis 1957). ${ }^{15}$

In 1959 Professors L.J. du Plessis, D.W. Kruger and J.H. Coetzee shocked the Afrikaner establishment with their views, published in the Sunday Times. They argued that black nationalism should not be ignored and that contact with the ANC should be started - views that were immediately repudiated by the National Party (see Coetzee 1998:277-280; Van Eeden 2006:490, 495). In the sixties Du Plessis had a serious conflict with Dr H.F. Verwoerd and warned against the danger of 'Verwoerdism'16. Du Plessis rejected the idea of 'blanke baasskap' [white supremacy] and opted to replace it with 'broederskap' [brotherhood]. Du Plessis did not oppose all aspects of the apartheid ideology, but his critical questions paved the way for further critical reflection.

I have already referred to the ACM, with its mouthpiece Word and Action, seated in Potchefstroom, which started a new critical reflection on the South African political situation. Professors J.H. Coetzee (1970-1981) and later L.M. du Plessis (1981-1986) (see Du Plessis 1988), editors of Word and Action, propagated a 'policy of justice' in many of their editorials. ${ }^{17}$ In 1976, an influential conference was launched by the ACM on the topic of justice in South Africa and many speakers queried the practise as well as the principles of apartheid with that of J.D. van der Vyver (see Van der Walt 1976:58-82) as the most profound. ${ }^{18}$

14.See the following (correct) comment by Meredith (2010): "In the context of the 1930 s, the greatest threat to Afrikanerdom was seen to come not from the blacks, as it was at a later stage, but from British imperialism and its allies in the Englishspeaking population.'

15.On L.J. du Plessis, see Van Wyk 1993:50-51 with references.

16.See Giliomee (2012:52-89) who presented a nuanced interpretation of the Verwoerd policy.

17.On many occasions Prof J.H. Coetzee was invited to address the delegates of the national synod of the GKSA during a tea time break and he would almost always emphasise a policy of justice.

18.Van der Vyver was (at the time) a member of the NHKA.The focus in this article is on the (members of) the GKSA. 
The conference followed in the tradition of John Calvin who put such a great emphasis on the concept of justice in his sermons and Institutes (Calvyn 1559). Only a few examples will suffice to illustrate this statement. In one of his sermons on the Decalogue, Calvin states that there are two essential things in life, viz. to serve God with a pure heart and to treat our fellow humans sincerely and justly (Calvijn n.d.:109). The purpose of the whole Law of God, he would argue, is the fulfilment of righteousness so that men may model their lives on the example of divine purity (Inst. 2.8.51). When Calvin deals with civil government, he takes Jeremiah 21:12 and 23:3 as key features: to administer justice and act justly implies protecting helpless people and resisting the oppressor (Inst. 4.20.9). It is understandable that Calvin as a theologian puts the concept of justice in a theological framework - justice rests on the veneration of the Lord (Inst. 2.8.11). Although Calvin accepts the fact that a Christian may show solidarity with his nation, he rejects any form of racism (see Kolfhaus 1949:332, 343, 352).

During this period Willem de Klerk, son of senator Jan de Klerk and elder brother of F.W. de Klerk, was an influential person in the South African context. As Dopper dominee he became well known for his invention of the concepts 'verlig' ['progressive'] and 'verkramp' ['conservative'] which he used at a SABRA Congress in 1966. After being a professor at the PU for CHE he became editor first of Die Transvaler in 1973 and then of Rapport until 1987. He also played a leading role in the formation of the Democratic Front in 1989. He was a progressive thinker and made many meaningful proposals, but mostly within the framework of the apartheid ideology, which, at a later stage, he openly rejected (see De Klerk, Duvenage \& Van Wyk 1972:323-334; De Klerk 1980; 2000). He was sharply criticized by Chris Louw (Boetman) (2000:13), son of a Dopper dominee, because he (De Klerk) stayed too long in the 'kraal' and because of his ambivalent approach (Louw had left the Dopper church). Louw (2001:161, 228-231) also launched a sharp attack on the Potchefstroom Calvinists, but he himself was part of Perskor until 1986 (Louw 2001:134, 140) and only saw the light while he was in London (Louw 2001:141, 145-146, 176). He almost totally ignored the critical role played by many Potchefstromers. ${ }^{19}$

There are colleagues who also refer to me as an opponent and critic of apartheid (Gaum 2011:110; Hofmeyr 2012:447), but I have always done so as a critic of the 'in-group'. I did not distance myself from the church and society, but always criticised in a manner of critical solidarity. Such criticism is not as sensational and notorious as the criticism of someone who belongs to the 'out-group' (who often criticises from a distance within the warm context of like-minded friends), but could sometimes be very exhausting and humiliating, especially when it is done within the context and tenseness of a synod meeting. ${ }^{20}$ I have hoped to follow the example of Christ in this regard (Jn 13:1).

19. Esterhuyse $(2012: 140-154,277-280)$ tells us more about the role Willem de Klerk played in the early talks with the ANC

20.On my own road to clarity, see Van Wyk (2015:475-484). The 'connected critic' criticises from within and the 'committed critic' criticises from without.
The process of critical re-evaluation was accompanied by some new initiatives, which today seem insignificant but were at that time sensational, not to say epoch-making. I refer to the following (see Coetzee 1998:273-289; Potgieter 1998:117-141): ${ }^{21}$

- In 1973 the PU for CHE became the first of the classic Afrikaans universities to admit non-white post-graduate students.

- In 1977 the critical Koinonia Declaration was published, designed and signed by many Potchefstromers. ${ }^{22}$

- In 1983 the PU for CHE became the first of the Afrikaans universities to admit non-white undergraduate students although it was under certain conditions (see W.E. Scott in Reinecke 1998:80). ${ }^{23}$

- In 1987 Theuns Eloff, then a reformed minister in Brooklyn, joined a group of Afrikaners who held secret talks with the then banned ANC in Dakar, which eventually led to his quitting the ministry (Eloff 2016:181). ${ }^{24}$ Eloff also played a key role during the Convention for a Democratic South Africa (CODESA) negotiations during the 1990s (Eloff 2016:11; Esterhuyse 2012:125). ${ }^{25}$

- Prof Marinus Wiechers, the former rector of UNISA and a member of the GKSA, played an important role in drawing up the South African Constitution (Republic of South Africa 1996), especially as far as the constitutional principles were concerned (see also Wiechers 1988). This Constitution is well-known for its Bill of Rights of which the key features are equality, human dignity and freedom and where 'equality' is almost another word for 'justice'. (Wiechers' contribution to the composition of the Namibian Constitution was even greater. $)^{26}$

- In 1995, the black and white theological training institutions of the GKSA at Hammanskraal and Potchefstroom were united - the first unification of such theological schools by one of the three Afrikaans churches.

- In 1997 a public confession of guilt (about apartheid) was published by three professors and one dominee from Potchefstroom. ${ }^{27}$

It was a time when outsiders also were looking at Potchefstroom for taking the initiative in criticising and abolishing apartheid. In 1985 Beyers Naudé (1985:172-173) remarked that, of the three Afrikaans churches, the GKSA

21.My colleague, Bennie van der Walt, drew my attention to the fact that during the eighties (even) the Potchefstromers had a lot of disagreements among themselves on main issues.

22.Persons involved were Elaine Botha, Lourens du Plessis, Theuns Eloff and Pont Venter (Coetzee 1998:283).

23.Scott describes this decision by the Board of the PU for CHE taken during the rectorate of Prof Tjaart van der Walt as 'die mees ingrypende koersverandering' ['the most radical change of direction' - author's translation].

24.At the Dakar conference, Mbeki was impressed by Theuns Eloff, the Dopper dominee (Esterhuyse 2012:125).

25. His Doctoral thesis prepared him well for the future negotiations (Eloff 1988).

26.Other Calvinists who played an important role in the composition of the Constitution (Republic of South Africa 1996) are professors Lourens du Plessis and Francois Venter.

27.Persons involved were Alwyn du Plessis, Bennie van der Walt, Amie van Wyk and Ponti Venter. Two of them (Van der Walt and Venter) presented the Confession to the Truth and Reconciliation Commission (TRC) in 1997 in East London (see Meiring 1999:289) and one of them (Amie van Wyk) to a meeting that revisited the TRC in
199. 1999:289) and one of
2014 in Stellenbosch. 
'resounded most seriously the truth of the gospel as far as race relations and human rights are concerned.' Jaap Durand (1985:50) commented that 'especially in the academic and theological circles of Potchefstroom and the Reformed Church [GKSA] the shift from an apartheid theology to a less apartheid-orientated theology is evident'. Earlier W.A. de Klerk (1976:342) confirmed that in Potchefstroom 'probably more of the original Calvin has survived than anywhere else' ${ }^{28}$

As far as church relations are concerned, a similar kind of development took place. The earliest decisions, approved by synods of the GKSA (Synods 1869, 1973), supported the idea of segregation in the church. Two small schisms because of the race question - took place in the congregations of Bethulie (1877) and Humpata, Angola (1908). The church model, which developed in the GKSA, can be described not as a 'volkskerk', but as a 'volkerekerk' and was formulated by Prof W.J. Snyman (see Van Wyk 1985; 1993:45-48) in the fifties and sixties of the 20th century. It implied that the church of Christ should manifest itself in each culture (volk) to the point of national synods (which held its first meeting in 1963), but these national synods should unite in one general multicultural synod. This General Synod of the GKSA, consisting of one 'white', one 'brown' and two 'black' national synods, met for the first time in 1965 in Potchefstroom. Looking back it seems like a minor event, but in the context of the stressful political situation of the sixties, it was epoch-making. Black and white in one synod with the whites by far in the minority!

This promising development of church unity, however, soon met with criticism from the 'younger churches': church unity should not start at the 'top' (synodical) level, but from 'below' in the local congregations, they argued. The volkerekerk model does not differ that much from the volkskerk model, for it put too much emphasis on the volk. What we need is not a volkskerk model, but a Godskerk model. The result of this criticism was that the general synod of the GKSA existed only until 1992 and were then discontinued.

\section{Phase 3: the triumph of truth (veritas vincet) (1990-2015)}

Phase 3 consists of a few culminating moments as far as race relations in church and society are concerned to which there will be referred now.

The first happened in 1991 and needs some background to fully understand it. The GKSA was one of the initiators of the Reformed Ecumenical Synod (RES) in 1946 and this synod was to play a very important role in the life of the GKSA. It helped the GKSA to avoid a sectarian attitude and approach in ecclesiology and to develop a permanent interest in

28.See also in this regard the complimentary statement by the influential DRC theologian, Johan Heyns (1979:230): 'It was in Potchefstroom that I discovered for the first time something of the tremendous depth and power of Calvinism.' ecumenical affairs. In 1991 the GKSA accepted the following important recommendation on race relations taken by the RES: 'the ideology of apartheid is a sin and the theological justification of it a heresy' (Acta GKSA 1991:160). ${ }^{29}$

There already has been referred to the fact that the two theological seminaries of the GKSA united in 1995. The consequence of this was, inter alia, that for the first time black students started to conduct worship services in 'white' congregations in Potchefstroom and surrounding towns. Black professors of which Derrick Mashau (2003) and Rantoa Letsosa (2006) were the first two, were called to lecture also to white students. A new era in church relations was born.

Earlier, there has been referred to the fact that the last General Synod of the GKSA stopped meeting in 1992, but it was reestablished in 2006 after the separate black and white classes were united in regional synods. The regional synods as well as the general synods were now fully multicultural - the first of the three Afrikaans churches to do so. Unfortunately, Synod Soutpansberg (Venda) decided not to join, although some of the Venda congregations did. Also (the black) classis, Tshwane, did not join. It must be added that much has to be done to improve and normalise mutual relations and unity between the different so-called 'black' and 'white' congregations and believers.

The focus will now be on the fact that it was a Calvinist who studied at Potchefstroom and was a member of the GKSA who brought about a radical change in South African society with his speech on the 2 February 1990, namely Mr F.W. de Klerk. How was it possible that a member of the GKSA and a Calvinist from Potchefstroom inaugurated the end of apartheid? What influence had he undergone to make this historical step? Was he influenced and inspired by the lectures of Prof L.J. du Plessis who taught political science at the PU for CHE?

Before paying more attention to the role of Mr F.W. de Klerk, there must be referred to the interesting fact that, at two critical phases in the life of Mr Nelson Mandela, two members of the GKSA played a crucial role, namely Mr De Klerk himself and also Judge F.L. Rumpff. It is observed that during the Treason Trial (1958-1961) 'everything hinged on the ethics and rectitude of Judge Rumpff' (Du Preez Bezdrop 2006:121). While many people hoped that the 'terrorist' Mandela and his comrades would be found guilty of violently overthrowing the country and turning it into a communist state, Rumpff declared on 20 March 1961 in the Old Synagogue in Pretoria that there was no proof for this charge

29.Worth mentioning is the fact that, already in 1983, the "black' Synod Midiands, which met in Metsi-A-Matala, rejected all forms of church and political apartheid. In 1989 the 'black' Synod Soutpansberg took the same decision. The critical conclusions on church and society by the Potchefstroom Mission Conference in 987, where I presented a paper, aroused a wave of indignation among 'white' congregations in the GKSA. I presented a paper here, but the papers were never published. Also see Van Wyk (1991:333-364) for my article on the witness of the church in a polarised South Africa. 
and that the accused should be released (see Du Preez Bezdrop 2006:121-124; Mandela 1995:247-249; Meredith 2010:181-191). ${ }^{30}$

The other person is Mr F.W. de Klerk who made his famous announcement on 2 February 1990 that led to the release of Mandela. Of course one must add that Rumpff and De Klerk did not operate in the first place as members of the GKSA, but the one as a judge and the other as a politician. Yet, from a Calvinist perspective, your Christian life and worldview influence the whole of life. Ethics and justice should not be separated.

Attention will now be given to the contribution of De Klerk, but a reference to an incident that happened in 1991 when a delegation of the PU for $\mathrm{CHE}$ attended a meeting of international Christian universities (IAPCHE) ${ }^{31}$ in Harare, will first be looked at. At one stage a delegate from the Netherlands launched a severe attack on the PU for CHE and asked the question: 'what did you do to stop and abolish apartheid?' What could we say, we sinners and culprits from Potchefstroom? Then another delegate from South Africa stood up and said: 'I have no relationship with the PU for CHE but I think that a university which produced a state president who dismantled apartheid, deserves some kind of appreciation.' This remark brought to an end the attack on the Potchefstroom delegation.

During a conference, which was held at Princeton University a Presbyterian minister, Alan Maker (2001:196-197) remarked that the NGK, because of its intense involvement in apartheid, could not produce a person like F.W. de Klerk, but the Doppers could. I regard this as an overstatement, because the NGK did produce personalities like Beyers Naudé (1995) and Willie Jonker (1998) - although they were theologians and not politicians.

A look into F.W. de Klerk's autobiography, Die laaste trek'n nuwe begin (1998), shows that the Potchefstroom University had 'an immense influence' on his development as he himself said (De Klerk 1998:52) (2) $^{32}$ quite a different experience than that of his contemporary, André P. Brink. ${ }^{33}$

What then prompted De Klerk to take the great step? ${ }^{34}$ His autobiography supplies the answer: the notion of justice played a crucial and decisive role in De Klerk's change of mind. Time and again he would return to this motivation.

30.See Mandela's remark (1995:249): Although Judge Rumpff gave the impression that he shared the point of view of the ruling party, 'yet, in the end, an essential fairness dominated his judgement'.

31. International Association for the Promotion of Christian Higher Education.

32. His brother, Willem de Klerk (1991:27), concurs with this statement. He (De Klerk 1991:25) is of the opinion that justice and justness became the leitmotiv in the life of F.W. de Klerk; 'justice' is the 'political credo' of F.W. De Klerk (p. 159).

33.See my article on Brink in Van Wyk (2015:389-405).

34.This question also worried Van Zyl Slabbert (2006:35). See Giliomee (2012:291-325) on the question whether De Klerk was moved by pragmatic reasons or considerations of principle or both. Also see Giliomee (2015:93): 'After his election as NP leader early in 1989, he (FW de Klerk) singled out morality as his main motivation for ending apartheid and for seeking a settlement.' According to Esterhuyse (2012:179), ending apartheid and for seeking a settlement.' According to Esterhuyse (2012:179),
De Klerk respected the idea of a constitutional state, although his final decision was De Klerk respected the idea of a constitutional state, although his final
more strategically motivated (p. 251) than based on morality (p. 226).
By no means, he said, should our sense of justice and humaneness be watered down (De Klerk 1998:59). When he was sworn in as state president of South Africa, he had the experience of standing before God and decided to tackle his task with the 'Biblical principles of justice, peace and love of one's neighbour' as his guidelines (De Klerk 1998:167). ${ }^{35}$

South African Calvinists have made many mistakes in the past, such as the support of a policy of apartheid and injustice during its first phase, but it is also true that Potchefstromers raised many critical questions about apartheid. It will always be a fact of history that the termination of apartheid as a legal system was initiated by a Calvinist who made justice his conclusive principle in social life (see Schutte 2005:664-665). Democracy in South Africa was initiated by a Calvinist, including a new Constitution (Republic of South Africa 1996) with worldwide acclaim. ${ }^{36}$

It is significant that the Dutch historian, Gerrit J. Schutte, differs from the view of Hexham and argues that the origin of the Afrikaner ideology must be blamed not on the Potchefstromers, but on the anti-Kuyperian nationalists like J.B.M. Hertzog, D.F. Malan and other volksnasionaliste (see Van der Schyff 2003:529, 530 $\left.{ }^{37}\right) .^{38}$ Scholtz (2016:102-105) draws our attention on even more: he mentions that 'most elements of the apartheid policy' were to be found in the segregation policy drawn up by a commission under the chairmanship of sir Godfrey Lagden who was appointed by lord Milner already in 1905.

To this, we may add the statement of De Gruchy (1991:12) that 'recent studies on the origin of Afrikaner political development reject any simplistic equation between the origins of apartheid and Calvinism' ${ }^{39}$

Another very important contribution De Klerk made to the South African society, which is worth mentioning, is his initiative to free the society from nuclear weapons with the signing of the Nuclear Non-proliferation Treaty in 1991 (Du Plessis 2016:12). Countries, which possess nuclear weapons, are very vulnerable in cases of terrorism as well as during a civil or international war. ${ }^{40}$

35.During his presidency I wrote several letters to De Klerk in which I encouraged him to follow a policy of justice. My book, Moraliteit en Verantwoordelikheid. Opstelle oor Politieke Etiek (1991), was dedicated to him and his wife Marike.

36.De Gruchy (2015:163) refers to the 'famous speech' of De Klerk, but does not relate it to his Calvinist background and convictions. Giliomee (2012:429) typifies the speech as follows: 'Sy toespraak op 2 Februarie was meesterlik, inderdaad een the speech as follows: 'Sy toespraak op 2 Februarie was meesterlik, inderdaad een van die groot oomblikke in die geskiedenis van Suid-Afrika en sonder twyfel een van die groot toesprake in die geskiedenis van die 20ste eeu.' ['His speech of 2 February was masterly, indeed one of the great moments in the history of South Africa and without doubt one of the great speeches in the history of the 20th century' author's translation]. However, Giliomee $(2012: 359,417)$ criticises De Klerk's dealing with the results of the Referendum of 1992, where power sharing was promised to the electorate and not the transferring of power.

37.See Scholtz (2016:87) with reference to Schutte, with the same conclusion.

38.It is significant that G. Cronje once acknowledged that he is the father of apartheid. Cronje (1945:10) argues that it is the will of God that there should be different races and volke (also see Diederichs 1936; see in this regard Scholtz 2016:87-95).

39.See Allan Boesak's appraisal and admiration of (a pure form of) Calvinism (2009:220, 278). Wentsel (1987:646) reminds us that 'Racism is to be found in every human being.

40.De Klerk's decision to withdraw from the Government of National Unity in 1996 was, in my view, a big mistake. With this step he not only withdrew a lot of skill and competence from society, but also stimulated the perception that black people and white people cannot govern together. 


\section{Conclusion}

Calvinism is closely associated with the five solisms of the Reformation of the 16th century, viz. soli Deo Gloria, solus Christus, sola fide, sola gratia and sola Scriptura. ${ }^{41}$ Special emphasis is laid on the sovereignty of God, the kingship of Christ and the authority of Scripture. It has been ensured that only the teachings of Scripture and not the pronouncements of the Pope or the decisions of synods should have the highest authority. But this is exactly where a fundamental question arises. Calvinists say 'Scripture alone', but is it the Scripture alone or are our interpretations of Scripture not always accompanied by our (also political) presuppositions and preoccupations? Why did serious Calvinists fall into the trap of developing a theological justification of an immoral and unjust policy like apartheid? What else could it be than being blinded by an ideology, ignoring Christology and focusing on a few biblical texts only (like Gn 11:1-9 and Ac 17:26) or reading into a text what was decided beforehand to find in it?

Once you have assumed the authority of Scripture you have to ensure that your understanding of the biblical message is correct. Christology (Heb 1:1-2) can here serve as a safeguard against a fundamentalist and non-contextual reading of the Bible. Precisely this was one of the flaws in the views of Totius.

To this, we must add something else. It seems that Calvinists have forgotten another sola, namely the solus Spiritus [the Spirit alone]. The interpretation of Scripture must be accompanied by the enlightenment of the Holy Spirit, for it is the Spirit alone who guides in all truth (Jn 16:13) and who opens hearts to grasp with all the saints how wide and long and high and deep the love of Christ is (Eph 3:18).

We have mentioned that the moral principle of justice played an important role in the theology of Calvin and I think it was this principle, more than anything else, that gradually undermined the ideology of apartheid and brought it to a fall. It was this principle that played a decisive role in the dismantling of apartheid by F.W. de Klerk. Apartheid was a policy of injustice against black people and brown people and it was in contradiction to the Law of God and the teaching of Christ. It should never have been justified, implemented, defended and promoted by people who called themselves Calvinists.

It is always very dangerous when a church identifies too closely with the history, experiences and ideals of the volk to which its members belong, because it undermines the character of Christ's church as a multicultural - and exemplary - phenomenon in a world of division and hostility (Eph 4:4-6).

41.See for example Vollmer (2008-2009:189-205) view of what Calvinism is. It is significant to note that the first translation Calvin's Institutes (Calvyn 1978) into Afrikaans (although in a shortened edition) was done by a Dopper dominee, A. Duvenage (1967-1978). The translation of the four volumes of the Institutes was also undertaken by of professor of the PU for CHE, HW Simpson (1984-1992), who was a member of the GKSA. As far as I know the first novel on Calvin in Afrikaan was also published by a member of the GKSA, Jansie van der Walt (1981) A shortened edition appeared later in English.
It would not be wrong to conclude that there were two versions of Calvinism active in South Africa in the 20th century - the one with a more naïve-orthodox approach reading the Bible in fundamentalist way, blinded by a nationalist ideology, and another one with a more critical and ethical tradition inspired by the message of the Reformation that sought to maintain the biblical principle of justice.

Twenty-two years after apartheid we envisage new challenges. We have abandoned division and are striving for (national) unity, but we still have to cope with the model of diversity while avoiding the danger of uniformity. The Union of South Africa, which came into existence in 1910, consists of at least 12 different cultures (including the Khoi-San) with different languages, while our Constitution (Republic of South Africa 1996) states 'that everyone has the right to use the language and to participate in the cultural life of their choice' (2.30) even to the point of self-determination (14.235). We have dismantled the policy of division (apartheid, separation, disunity), but now are endangered by an idea that unity means uniformity. We have rejected the dictatorship of the minority, but are threatened by a dictatorship of the majority. It is our task to discover a balance between the concepts of unity and diversity, the balance between being a South African and being a Khoi-San in the full sense of the word. This approach favours the idea that a plural democracy would have been a better option for a multi-cultural South Africa than a liberal democracy - which we now experience (see Degenaar 1976:92-109; 1980:109-138).

Unity and diversity, not uniformity and division is our new challenge in the new South Africa. Maybe the church of Christ as a sign of God's kingdom and new world, can serve as a model to really experience true unity within diversity.

Younger Calvinists from the GKSA, like Theuns Eloff (executive of the F.W. de Klerk Stigting) and Flip Buys (chairman of Solidariteit), nowadays try (maybe in different ways) to avoid the dangers of the old apartheid ideology, yet wrestling with the new dilemma of how to relate the concepts of national unity to cultural diversity.

To conclude: From a theological perspective, it is evident that the concept of justice (and righteousness) - accompanied by that of love - plays a prominent and decisive role in all religious and human relations. It is a key feature in the message of almost all the prophets of Israel. In the New Testament, this approach reaches its culmination. Jesus calls upon his followers to seek first the kingdom (of God) and its righteousness (Mt 6:33) and Paul refers to righteousness as one of the key characteristics of the kingdom of God (Rm 14:17). When Peter singles out one word to describe the new creation promised by God, he refers to the home of righteousness' (2 Pt 3:13). The new creation will be a place where righteousness and justice reign. This is the world we should anticipate right now in all our thoughts, words and actions. 


\section{Acknowledgements Competing interests}

The author declares that he has no financial or personal relationships which may have inappropriately influenced him in writing this article.

\section{References}

Acta GKSA, 1991, Handelinge van die vier en veertigste Nasionale Sinode van die Gereformeerde Kerke in Suid-Afrika te Potchefstroom, GKSA, Potchefstroom.

Allen, J., 2006, Rabble-Rouser for peace: the authorized biography of Desmond Tutu, Random House, Johannesburg.

Badenhorst, F.G., 1939, Die rassevraagstuk, veral betreffende Suid-Afrika, in die lig van die Gereformeerde etiek, Noord-Hollandse Uitgewers, Amsterdam.

Beyers Naudé, C.F., 1985, 'Op weg naar een belijdende kerk', in H. Berkhof et al. (eds.), Met de moed der hoop: opstellen aangeboden aan dr C.F. Beyers Naudé, pp. 167-179, Ten Have, Baarn.

Beyers Naudé, C.F., 1995, My land van hoop: die lewe van Beyers Naudé, Human \& Rouseau, Kaapstad.

Boesak, A., 2009, Running with horses: reflections of an accidental politician, Joho, Cape Town.

Bossenbroek, M., 2012, Die Boereoorlog, vert. A-M. Mischke, Athenaeum-Polak \& Van Gennep, Amsterdam

Botha, A.J., 1986, Die evolusie van 'n volksteologie, UWK, Belville.

Calvijn, J., n.d., Het gepredigte Woord: preeken van Johannes Calvijn over den Decaloog, deel IV, vert. J. Douma \& W.H. vd Vegt, Wever, Franeker.

Calvyn, J., 1559, Institusie van die Christelike godsdiens, 1984, 1986, 1988, 1992 vol. 1-4, vert. H.W. Simpson, CJBF, Potchefstroom

Calvyn, J., [1967] 1978, Institusie of onderwysing in die Christelike godsdiens vert. A. Duvenage, NG Kerkboekhandel, Pretoria.

Cameron T. \& Spies, S.B. (reds.), 1991, Nuwe geskiedenis van Suid-Afrika, Human \& Rousseau, Kaapstad.

Coetzee, C.J. 1998, 'Die PU vir CHO en die rasse- en volkerkeproblematiek - enkele aspekte', in C.J. Reinecke (red.), Verkennings in oorgang: gedagtes by die 125 -jarige bestaansjaar van die PU vir CHO-1994, bl. 273-289, Koers: Bulletin vir Christelike Wetenskap, suppl. ser. 1.

Cronje, G., 1945, 'n Tuiste vir die nageslag: die blywende oplossing van Suid-Afrika se rassevraagstukke, Publicite, Johannesburg.

d'Assonville, V.E., 1993, Dit is Totius - J D du Toit 1977-1953, Marnix, Lynnwoodrif.

Degenaar, J.J., 1976, Moraliteit en politiek, Tafelberg, Kaapstad.

Degenaar, J.J., 1980, Voortbestaan in geregtigheid: opstelle oor die politieke rol van die Afrikaner, Tafelberg, Kaapstad.

De Gruchy, J.W., 1991, Liberating reformed theology: a South African contribution Eerdmans, Grand Rapids.

De Gruchy, J.W., 1998, 'Recovering ecumenical vision and commitment in a postecumenical era', Journal of Theology for Southern Africa 102, 1-12, Nov.

De Gruchy, J.W., 2015, I have come a long way, Lux Verbi, Cape Town.

De Gruchy, J.W. \& De Gruchy, S., 2004, The church struggle in South Africa, 25th anniversary edn., SCM Press, London.

De Klerk, F.W., 1998, Die laaste trek - 'n nuwe begin: die outobiografie, Human \& Rousseau, Kaapstad.

De Klerk, W.A., 1976, The puritans in Africa: a story of Afrikanerdom, Penquin, Hammandsworth

De Klerk, W., 1980, Politieke gesprek, Perskor, Johannesburg.

De Klerk, W., 1991, F.W. de Klerk: die man van sy tyd, Tafelberg, Kaapstad.

De Klerk, W., 2000, Afrikaners: kroes, kras, kordaat, Human \& Rousseau, Kaapstad.

De Klerk, W.J., Duvenage, B. \& Van Wyk, J.H., 1972, Roeping en werklikheid, Potchefstroom Herald, Potchefstroom. ${ }^{42}$

Diederichs, N., 1936, Nasionalisme as lewensbeskouing en sy verhouding tot internasionalisme, Nasionale Pers, Kaapstad.

Du Plessis, C., 2016, 'Kernwapens: FW, SA geprys', Beeld, 4 September, bl. 12.

Du Plessis, L.J., 1957, Apartheid, Ja of nee of ja-nee? Broeder Buskes broederlik beantwoord, Pro Rege, Potchefstroom.

Du Plessis, L.M., 1988, Tien Perspektiewe: gesprekke oor die toekoms, Tafelberg, Kaapstad.

Du Plessis, S.J., 1952, President Kruger aan die woord: verkiesingsmanifeste, intreeredes en toesprake van president SJP Kruger, Sacum, Bloemfontein.

Du Preez Bezdrop, A.M., 2006, The Nelson Mandela Story, Samoja Books, Kestell.

Durand, J., 1985, 'Afrikaner Piety and Dissent', in C. Villa-Vicencio \& J. W. de Gruchy (eds.), Resistance and Hope: South African Essays in Honour of Beyers Naude, pp. 39-51, David Philip, Cape Town.

42.This Jan Hendrik van Wyk (a pedagogue) must be distinguished from the author of this article, Jan-Harm van Wyk (a theologian).
Eloff, T., 1988, Staatsowerheid en geregtigheid met besondere verwysing na rasseklasifikasie, Th.D.-proefskrif, Fakulteit Teologie, Potchefstroomse Universiteit rasseklasifikasie, Th.D.-proefsk
vir Christelike Hoër Onderwys.

Eloff, T., 2016, Wat nou Suid-Afrika?, Tafelberg, Kaapstad.

Esterhuyse, W., 2012, Eindstryd: geheime gesprekke en die einde van apartheid, Tafelberg, Kaapstad.

Gaum, F., 2011, Fluit-fluit die kerk is uit? Rigtingwysers vir die oorlewing en geloofwaardigheid van die kerk, Bybel-Media, Wellington.

Giliomee, H., 2003, The Afrikaners: biography of a people, Tafelberg, Cape Town.

Giliomee, H., 2012, Die laaste Afrikaner-leiers: 'n opperste toets van mag, Tafelberg, Kaapstad.

Giliomee, H., 2015, 'nelson Mandela and the last Afrikaner leaders', New Contree 72, 69-96, July.

Giliomee, H. \& Mbenga, B. (reds.), 2007, Nuwe Geskiedenis van Suid-Afrika, Tafelberg, Kaapstad.

Heyns, J.A., 1979, 'Enkele aspekte van die Calvinisme', Koers: Bulletin vir Christelike Wetenskap 44(4), 230-236

Hexham, I., 1981, The Irony of Apartheid: the struggle for National Independence of Afrikaner Calvinism against British Imperialism, Edwin Mellen, New York.

Hofmeyr, J.W., 2012, 'Die Afrikaanse kerke in die 20ste eeu', in F. Pretorius (red.), Die Geskiedenis van Suid-Afrika: van voortye tot vandag, bl. 443-452, Tafelberg, Kaapstad.

Inst., see Calvyn 1559

Jonker, W., 1998, Selfs die kerk kan verander, Tafelberg, Kaapstad.

Kinghorn, J. (red.), 1986, Die NG Kerk en apartheid, Macmillan, Braamfontein.

Kolfhaus, D.W., 1949, Vom christlichen Leben nach Johannes Calvin, Neukirchen Kreis Moers.

Kruger, D.W., 1961, Paul Kruger, Deel I, 1825-1883, Dagbreek Boekhandel, Johannesburg.

Kruger, D.W., 1963, Paul Kruger, Deel II, 1883-1904, Afrikaanse Pers, Johannesburg.

Kuyper, A., 1959, Het Calvinisme: Zes Stonelezingen, Kampen, Kok.

Louw, C., 2000, 'Boetman is die bliksem in', Beeld, 3 Mei, bl. 13.

Louw, C., 2001, Boetman en die swanesang van die verligtes, Human \& Rousseau, Kaapstad.

Maker, A., 2001, 'Something new out of Africa: Christian and African spirituality meet to give hope for world humanity', The Princeton Seminary Bulletin 22(2), 185-202.

Mandela, N., 1995, Long Walk to Freedom: the autobiography of Nelson Mandela, Macdonald Purnell, Randburg.

Meiring, P., 1999, Kroniek van die Waarheidskommissie: op reis deur die verlede en die hede na die toekoms van Suid-Afrika, Carpe Diem, Vanderbijlpark.

Meredith, M., 2010, Mandela: a Biography, Jonathan Ball, Johannesburg.

Moody, T.D., 1975, The Rise of Afrikanerdom: power, apartheid and the Afrikaner civil religion, University of California Press, Berkeley.

Ntoane, L.R.L., 1983, A Cry for Life: An Interpretation of 'Calvinism' and Calvin, Kok, Kampen.

Potgieter, P.J.J.S., 1998, 'Die PU vir CHO as Afrikaanse Universiteit', in C.J. Reinecke, (red.), Verkennings in oorgang: gedagtes by die 125-jarige bestaansjaar van die PU vir CHO - 1994, bl. 117-141, Koers: Bulletin vir Christelike Wetenskap, suppl. ser. 1.

Pretorius, F., 1998, Die Anglo-Boereoorlog 1899-1902, Struik, Kaapstad.

Pretorius, F.J. (red.), 2012, Geskiedenis van Suid-Afrika: van voortye tot vandag, Tafelberg, Kaapstad.

Reinecke, C.J. (red.), 1998, Verkennings en oorgang: gedagtes by die 125-jarige bestaansjaar van die PU vir CHO - 1994, Koers: Bulletin vir Christelike Wetenskap suppl. ser. 1.

Republic of South Africa, 1996, Constitution of the Republic of South Africa, Government Printer, Pretoria.

Scholtz, LvR., 2008, 'Anglo-Boereoorlog (1899-1902)', in F. Gaum, A. Boesak, \& W. Botha (reds.), Christelike Kern-Ensiklopedie, bl. 45-46, Lux Verbi BM, Wellington.

Scholtz, L., 2016, Kruispaaie: Afrikanerkeuses in die 19de en 20ste eeu, Kraal Uitgewers, Pretoria.

Schutte, G., 2005, De Vrije Universiteit en Zuid-Afrika 1880-2005, deel 2, Zoetermeer, Meinema.

Smit, D.J., 2007, Essays in public theology, Sun Press, Stellenbosch. (Collected Essays, 1)

Strydom, J.G., 1941, 'Die rassevraagstuk in Suid-Afrika' in H.G. Stoker \& J.D. Vorster (reds.), Koers in die krisis, bl. 43-255, Pro Ecclesia, Stellenbosch.

Strydom, J.G., 1942, Die rassevraagstuk en die toekoms van die blankes in Suid-Afrika, NGK in die OVS, Bloemfontein.

Van der Schyff, P.F., 2003, Wonderdaad ...! Die Puk tot 1951: wording, vestiging en selfstandigheid, $\mathrm{PU}$ vir $\mathrm{CHO}$, Potchefstroom.

Van der Vyver, G.C.P., 1969, My Erfenis is vir my mooi: gedenkboek by die Eeufees van die Teologiese Skool van die Gereformeerde Kerk in Suid-Afrika en van die Potchefstroomse Universiteit vir Christelike Hoër Onderwys, Kalvyn Jubileum Boekefonds, Potchefstroom

Van der Walt, J., 1981, Johannes Calvyn: 'n jeugroman, CJBF, Potchefstroom. 
Van der Walt, T. (ed.), 1976, Geregtigheid en die Suid-Afrikaanse samelewing, PU vir CHO, Potchefstroom.

Van Eeden, E.S. (red.), 2006, 'In U Lig': die PU vir CHO - van selfstandigwording to samesmelting, 1951-2004, Noordwes-Universiteit, Potchefstroomkampus, Potchefstroom.

Van Jaarsveld, F.A., 1979, Die evolusie van apartheid en ander geskiedkundige opstelle, Tafelberg, Kaapstad.

Van Wyk, J.H., 1985, Man van die derde weg: W.J. Syman as teoloog, Institute for Reformational Studies, Potchefstroom.

Van Wyk, J.H., 1991, Moraliteit en verantwoordelikheid: opstelle oor politieke etiek, $\mathrm{PU}$ vir CHO, Potchefstroom

Van Wyk, J.H., 1993, 'Homo Dei': 'n prinsipiële besinning oor enkele mensbeskouings, waaronder dié van Calvyn, In die Skriflig 27, suppl. ser. 1.

Van Wyk, J.H. 1994, 'Reviews: d'Assonville, V.E.: dit is Totius. J.D. du Toit 1877-1953, In die Skriflig 28(4), 679-682.
Van Wyk, J.H., 2001, Etiek en eksistensie - in koninkryksperspektief, Potchefstroom Teologiese Publikasies, Potchefstroom.

Van Wyk, J.H., 2015, Teologie van die koninkryk: studies in dogmatiek en etiek, Vanwyk, Pretoria.

Van Zyl Slabbert, F., 2006, Duskant die geskiedenis: 'n persoonlike terugblik op die politieke oorgang in Suid-Afrika, Tafelberg, Kaapstad.

Vollmer, P., 2008-2009, John Calvin: man of the millennium, The Vision Forum, San Antonio, Texas.

Wentsel, B., 1987, God en mens verzoend: Godsleer, mensleer en zondeleer, Kok, Kampen. (Dogmatiek deel 3a).

Wessels, E. \& Raath, A.W.G, (reds.), 2012, Onthou! Kronieke van vroue- en kinderlyding, 1899-1902, Kraal Uitgewers, Pretoria.

Wiechers, M., 1988, 'n Politieke idiotikon vir Suid-Afrika, Tafelberg, Kaapstad. 